\section{Evaluating Peat Substrates Amended with Pine Wood Fiber for Nitrogen Immobilization and Effects on Plant Performance with Container-grown Petunia}

\author{
Crysta N. Harris ${ }^{1}$, Ryan W. Dickson ${ }^{2}$, Paul R. Fisher ${ }^{3}$, \\ Brian E. Jackson ${ }^{4}$, and Anissa M. Poleatewich ${ }^{1}$
}

AdDitional InDEX wORDs. consumer, floriculture, Petunia $\times$ bybrida, pine tree substrate, production, soilless substrate

Summary. Pine (Pinus sp.) wood products have potential to immobilize fertilizer nitrogen $(\mathrm{N})$ and influence plant growth when used in soilless substrates for the production of containerized floriculture crops. Peat substrate was amended with (by volume) $30 \%$ pine wood fiber (peat:fiber) during a production phase with fertigation and a simulated consumer retail phase with clear-water irrigation using containergrown 'Supertunia Vista Bubblegum' petunia (Petunia $\times$ bybrida). The objective was to evaluate substrate effects on substrate and plant tissue nutrient level and plant growth, with an emphasis on evaluating $\mathrm{N}$ immobilization from wood product amendments. Substrates consisting of peat amended with hammer-milled pine wood (peat:wood) or coconut (Cocos nucifera) coir (peat:coir) were used for comparison, and a $100 \%$ peat substrate (peat) served as a control. In Expt. 1, amending peat with pine wood fiber had no effect on leaf SPAD chlorophyll index, shoot growth, plant height and width, substrate $\mathrm{N}$, or percent shoot tissue $\mathrm{N}$ at the end-of-production. In Expt. 2, plants grown in peat:fiber had reduced flower number, plant height and width, and shoot growth compared with plants grown in the $100 \%$ peat control. However, petunia grown in peat:fiber substrates maintained dark-green foliage with high leaf SPAD chlorophyll index values $(\geq 44.4)$ and $\geq 45$ flowers/plant, and therefore were considered marketable plants. During the production phase in both Expts. 1 and 2, $\mathrm{N}$ concentrations remained within the target range for petunia in both the shoot tissue and root-zone for all substrates. In addition, there was no statistical evidence of $\mathrm{N}$ immobilization for any substrate blend for either of the $\mathrm{N}$ drawdown procedures. In both Expts. 1 and 2, root-zone nutrients became depleted during the consumer phase when irrigation was with clear water (no fertilizer), and petunia developed uniform symptoms of leaf chlorosis and $\mathrm{N}$ deficiency. Results of this study indicate that peat amended with $30 \%$ pine wood fiber, hammer-milled pine wood, and coconut can be used for production of containerized petunia with minimal effects on plant growth or need to adjust the fertilizer program. However, increasing pine wood to $>\mathbf{3 0} \%$ of the substrate volume may require growers to increase fertilization and adjust irrigation practices to compensate for greater risk of $\mathrm{N}$ immobilization and changes in substrate physical properties.

S oilless substrates containing wood fiber are increasingly being used for the production of containerized floriculture crops in the United States. This is partially a result of increasing concerns regarding the environmental sustainability of sphagnum peat harvesting (Barrett et al., 2016; Maher et al., 2008), in addition to increasing costs to manufacture and transport peat and other substrate components. Substrates containing (by volume) $20 \%$ to $40 \%$ wood fiber as a substrate amendment or replacement for peatmoss, perlite, and other common soilless components have gained significant market share among floriculture operations in North America (Drotleff, 2018).
Wood fiber components used in soilless substrates have potential to immobilize fertilizer $\mathrm{N}$ and reduce N uptake by plants (Blok et al., 2008; Handreck, 1992a, 1992b, 1993; Jackson et al., 2009; Maher et al.,
2008; Prasad, 1996a). Substrates with a carbon:N (C:N) ratio exceeding 30:1 tend to immobilize $\mathrm{N}$ due to microbial decomposition of the available $\mathrm{C}$, a process that requires $\mathrm{N}$ (Bunt, 1988; Nelson, 2011). Wood components such as composted barks, hammermilled wood materials, and sawdust can have C:N ratios of 300:1 or greater (Maher et al., 2008; Nelson, 2011; Prasad, 1996b), and have high potential to immobilize $\mathrm{N}$ from applied water-soluble fertilizers. Non-wood components that have high C:N ratios, such as coconut (Cocos sp.) coir fiber, can also immobilize $\mathrm{N}$ (Maher et al., 2008; Prasad, 1996a). In contrast, other organic materials such as peatmosses and organic composts tend to have a near zero $\mathrm{N}$ immobilization effect, or mineralize $\mathrm{N}$ (release additional $\mathrm{N}$ ) during microbial decomposition (Bunt, 1988; Prasad, 1980; Raviv, 2005). Factors that affect microbial activity also tend to influence $\mathrm{N}$ immobilization, including substrate temperature, moisture, $\mathrm{pH}$, oxygen level, $\mathrm{N}$ form, and C source (Geisseler et al., 2010; Handreck, 1993; Jackson et al., 2009; Schulten and Schnitzer, 1998).

Incorporating wood fiber components into peat-based soilless substrates can increase the amount of fertilizer $\mathrm{N}$ needed during production as a result of greater $\mathrm{N}$ immobilization (Gruda et al., 2000; Jackson et al., 2008; Maher et al., 2008; Prasad, 1996a). Previous substrate research with various wood components has shown that increasing the proportion of wood increases the amount of $\mathrm{N}$ required for optimal plant growth (Handreck, 1993; Jackson et al., 2008; Wright et al., 2008), and therefore similar results may be expected with increasing wood fiber components. Wood materials can differ in their potential to immobilize N (Handreck, 1993; Nelson, 2011; Prasad, 1996b), and also influence

\begin{tabular}{llll}
\hline $\begin{array}{l}\text { Units } \\
\begin{array}{l}\text { To convert U.S. to SI, } \\
\text { multiply by }\end{array}\end{array}$ & U.S. unit & SI unit & $\begin{array}{l}\text { To convert SI to U.S., } \\
\text { multiply by }\end{array}$ \\
\hline 10 & $\%$ & $\mathrm{~g} \cdot \mathrm{L}^{-1}$ & 0.1 \\
29.5735 & $\mathrm{fl} \mathrm{oz}$ & $\mathrm{mL}$ & 0.0338 \\
2.54 & inch $(\mathrm{es})$ & $\mathrm{cm}$ & 0.3937 \\
1 & $\mathrm{mmho} / \mathrm{cm}$ & $\mathrm{mS} \cdot \mathrm{cm}^{-1}$ & 1 \\
28.3495 & $\mathrm{oz}$ & $\mathrm{g}$ & 0.0353 \\
28,350 & $\mathrm{oz}$ & $\mathrm{mg}$ & $3.5274 \times 10^{-5}$ \\
1 & $\mathrm{ppm}$ & $\mathrm{mg} \cdot \mathrm{L}^{-1}$ & 1 \\
0.001 & $\mathrm{ppm}$ & $\mathrm{mL} \cdot \mathrm{L}^{-1}$ & 1000 \\
$\left({ }^{\circ} \mathrm{F}-32\right) \div 1.8$ & ${ }^{\circ} \mathrm{F}$ & ${ }^{\circ} \mathrm{C}$ & $\left({ }^{\circ} \mathrm{C} \times 1.8\right)+32$
\end{tabular}


plant growth by affecting various substrate physical properties (Argo, 1998a, 1998b; Bunt, 1988; Maher et al., 2008). There is a need to evaluate peat-based substrates containing wood fiber components for effects on $\mathrm{N}$ immobilization and plant growth to establish updated best management practices for commercial floriculture operations.

The objective was to evaluate substrate effects on substrate and plant tissue nutrient level and plant growth, with an emphasis on evaluating $\mathrm{N}$ immobilization from wood fiber components. Two greenhouse experiments were conducted to evaluate plant growth and $\mathrm{N}$ level for peat substrate amended with (by volume) $30 \%$ expanded pine (Pinus sp.) wood fiber during a production and simulated consumer retail phase with container-grown petunia (Petunia $\times$ bybrida). Substrates consisting of peat amended with either 30\% hammer-milled pine wood or $30 \%$ coconut coir, in addition to $100 \%$ peat substrate, were included for comparison. In Expt. 2, the same substrate blends, but without plants, were evaluated in the laboratory for physical properties and potential to immobilize $\mathrm{N}$ using the Handreck (1992a) N drawdown index (NDI) method and the Association of German Agricultural Analytic and Research Institute's (VDLUFA, 2007) procedure for testing $\mathrm{N}$ immobilization and mineralization in soilless

Received for publication 21 Oct. 2019. Accepted for publication 18 Nov. 2019.

Published online 31 December 2019.

${ }^{1}$ Department of Agriculture, Nutrition, and Food Systems, University of New Hampshire, Durham, NH 03824

${ }^{2}$ Department of Horticulture, University of Arkansas, Fayetteville, AR 72701

${ }^{3}$ Institute for Food and Agricultural Science, University of Florida, Gainesville, FL 32611

${ }^{4}$ Department of Horticultural Science, North Carolina State University, Raleigh, NC 27695

We thank Pleasant View Gardens, Pindstrup, KlasmannDielman, and industry partners of the Floriculture Research Alliance (floriculturealliance.org) for supporting this research and for donating materials. This research was also supported by the New Hampshire Agricultural Experiment Station, the U.S. Department of Agriculture (USDA) National Institute of Food and Agriculture project \#165958, and USDA Agricultural Research Service Floriculture and Nursery Research Initiative project \#58-3607-8-725.

R.W.D. is the corresponding author. E-mail: ryand@ uark.edu.

This is an open access article distributed under the CC BY-NC-ND license (https://creativecommons.org/ licenses/by-nc-nd/4.0/).

https://doi.org/10.21273/HORTTECH04526-19 substrates. We hypothesized that peat containing pine wood fiber and hammer-milled pine wood would increase $\mathrm{N}$ immobilization, reduce $\mathrm{N}$ uptake, and decrease plant growth.

\section{Materials and methods Expt. 1: University of Florida greenhouse evaluation of substrate amendments with a single peat source}

In 2017 , a single-factor experiment evaluated four substrates consisting of sphagnum peat amended with pine wood fiber, hammer-milled pine wood, and coconut coir fiber with container-grown 'Supertunia Vista Bubblegum' petunia. The experiment was conducted in a controlled-environment polycarbonate greenhouse at the University of Florida in Gainesville (lat. $29.6516^{\circ} \mathrm{N}$, long. $82.3248^{\circ} \mathrm{W}$ ), and plant growth was evaluated during a production phase and simulated retail consumer phase. Daily light integral (DLI) and average daily air temperature (ADT) during the experiment were (mean \pm SD) $15.7 \pm 4.6 \mathrm{~mol} \cdot \mathrm{m}^{-2} \cdot \mathrm{d}^{-1}$ and $23.5 \pm$ $1.9^{\circ} \mathrm{C}$, respectively, measured using a portable data logger (WatchDog 2475 Plant Growth Station; Spectrum Technologies, Aurora, IL).

SUBSTRATE BLENDS AND PLANT CULTURE. Four substrate blend treatments consisted of (by volume) 100:0 sphagnum peatmoss (peat), 70:30 peat:coconut coir fiber (peat:coir), 70:30 peat:hammer-milled pine wood (peat:wood), and 70:30 peat:pine wood fiber (peat:fiber). Substrates were formulated using Latvian sphagnum peat (Peat Moss Professional-Grower Grade; Pindstrup, Ryomgaard, Denmark), containing long fibers and little dust [von Post scale 2-3 (Puustjarvi and Robertson, 1975)], coconut coir fiber (Black Gold ${ }^{\circledR}$ Just Coir; Sun Gro Horticulture, Agawam, MA), hammermilled loblolly pine ( Pinus taeda) wood (Young's Plant Farm, Auburn, AL), and expanded European pine wood fiber (Forest Gold ${ }^{\circledR}$, Pindstrup). Wetting agent (PsiMatric; Aquatrols, Paulsboro, NJ) was added at 0.15 $\mathrm{mL} \cdot \mathrm{L}^{-1}$ of substrate.

On 16 Feb. 2017, vegetatively propagated cuttings of 'Supertunia Vista Bubblegum' petunia were obtained from a commercial propagator (Pleasant View Gardens, Louden, $\mathrm{NH}$ ) and were transplanted from 128cell trays into 8-inch-diameter plastic azalea containers filled with each of the four substrate treatments (Poppelmann Plastics US, Claremont, NC) at one plant per container. Each container represented one replicate. Eight replicates per substrate blend treatment were arranged on eight greenhouse benches using a randomized complete block design, where one bench served as one block. Initial substrate $\mathrm{pH}$ and electrical conductivity (EC) was measured in each replicate using the pourthrough method described by Wright (1986) using a benchtop $\mathrm{pH}$ and EC meter (Orion Dual Star; Thermo Fisher Scientific, Waltham, MA).

Plants were fertilized at transplant and at each subsequent irrigation event using a $17 \mathrm{~N}-2.2 \mathrm{P}-14.1 \mathrm{~K}-4.0 \mathrm{Ca}-$ $1.0 \mathrm{Mg}$ commercial water-soluble fertilizer (GreenCare Fertilizers, Kankakee, IL) mixed with de-ionized water at $200 \mathrm{ppm} \mathrm{N}$. Irrigation occurred once the moisture content across substrate blends dried to an average of $50 \%$ of the maximum water-holding capacity. Moisture content was determined by periodically placing randomly selected containers for each substrate blend on a weighing scale, where container weight had previously been correlated with moisture content for each blend. Each container received $500 \mathrm{~mL}$ of fertilizer solution at each irrigation, resulting in a standard amount of $\mathrm{N}$ delivered per plant. Plastic saucers placed under each container collected any leachate after irrigation and allowed for reabsorption into the substrate. At $21 \mathrm{~d}$ after transplant, the plant canopy for each treatment replicate was pruned around the container edge to a uniform height and width of 10 and $20 \mathrm{~cm}$, respectively, to promote a compact growth habit and a flush of new growth.

END-OF-PRODUCTION DATA COLLECTION. On 30 Mar. 2017 (42 d after transplant), data were collected for the production phase of the experiment. Substrate $\mathrm{pH}$ and EC were measured in leachate collected from each container replicate using the pour-through method described by Wright (1986), using a benchtop meter (Orion Dual Star). Leachate samples $(20 \mathrm{~mL})$ from each container were analyzed for ammonium- $\mathrm{N}\left(\mathrm{NH}_{4}-\mathrm{N}\right)$ and nitrate $\left(\mathrm{NO}_{3}\right)^{-}$ $\mathrm{N}$ concentrations using automated and semiautomated colorimetry (University of Florida Soil Testing 
Laboratory, Gainesville, FL), and N forms were summed for total $\mathrm{N}$ concentration. Percent shoot tissue N was measured by harvesting $20 \mathrm{~g}$ of recently mature and fully expanded leaf tissue per replicate, rinsing with $0.05 \mathrm{~N}$ hydrochloric acid $(\mathrm{HCl})$ followed by de-ionized water, and ovendrying at $70{ }^{\circ} \mathrm{C}$ for $2 \mathrm{~d}$. Dry shoot tissue was ground to pass through a 0.017-inch sieve, and $\mathrm{N}$ was measured [using the persulfate digestion method described by Purcell and King (1996)] at Quality Analytical Laboratories (Panama City, FL).

Leaf greenness was determined by nondestructively measuring leaf SPAD chlorophyll index for each replicate using a portable leaf SPAD meter (Minolta leaf SPAD meter; Spectrum Technologies). Each replicate value was the average of five leaf SPAD chlorophyll measurements from recently mature leaves, from randomly selected shoots per plant. Flowering was measured as the total number of open flowers per replicate. Plant dimensions were measured as the greatest height (centimeters) from the substrate surface and greatest width (centimeters) of the foliage per replicate.

END-OF-CONSUMER DATA COLLECTION. After the production phase, all replicates were grown for an additional $6 \mathrm{l} \mathrm{d}$ for a simulated retail consumer phase. Containers remained in the same greenhouse but were irrigated only with de-ionized water (no fertilizer nutrients) following the irrigation methods previously described for the production phase. Final data collection occurred on 30 May 2017 (103 d after transplant). Substrate $\mathrm{pH}$ and EC, leaf SPAD chlorophyll index, flower number, plant height and width data were collected as described for end-of-production data collection. Plants were destructively sampled to measure final shoot dry weight, tissue $\mathrm{N}$, and total shoot $\mathrm{N}$ per plant.

Statistical analysis. Data from the end-of-production and consumer phases were analyzed separately. Analysis of variance with PROC GLM in SAS (version 9.4; SAS Institute, Cary, NC) was used to evaluate substrate effects on substrate $\mathrm{pH}$ and EC, plant height and width, leaf SPAD chlorophyll index, flower number, substrate $\mathrm{N}$ concentration, and percent $\mathrm{N}$ in dry shoot tissue at the end-of-production phase.
Analysis of variance with PROC GLM was used to evaluate the same parameters at the end-of-consumer phase, with the addition of shoot dry weight gain. Mean separation used Tukey's honestly significant difference (HSD) at $\alpha=0.05$.

\section{Expt. 2: University of New Hampshire greenhouse evaluation of substrate amendments with two peat sources}

In 2017, a greenhouse experiment evaluated the same substrate blends used in Expt. 1 (peat, peat:coir, peat:wood, peat:fiber), but formulated using two different commercial sources of sphagnum peat and pine wood fiber [from Pindstrup and Klasmann-Deilmann (Geeste, Germany)]. The experiment was conducted in a controlled-environment glass greenhouse at the University of New Hampshire, Durham (lat. $35.9940^{\circ} \mathrm{N}$, long. $78.8986^{\circ} \mathrm{W}$ ), where DLI and ADT during the experiment were $($ mean $\pm \mathrm{SD}) 19.0 \pm$ $8.3 \mathrm{~mol} \cdot \mathrm{m}^{-2} \cdot \mathrm{d}^{-1}$ and $23.0 \pm 3.8^{\circ} \mathrm{C}$, respectively, measured using a portable data logger (WatchDog 2475 Plant Growth Station, Spectrum Technologies).

Substrate BLENDS AND PLANT CULTURe. Sphagnum peat and pine wood fiber from two different commercial sources (sources 1 and 2) were used to formulate four substrate blends for a total of eight substrates (four substrate blends $\times$ two peat and wood fiber sources).

Source 1 (Pindstrup) blends consisted of (by volume) 100:0 peat, 70:30 peat:coir, 70:30 peat:wood, and 70:30 peat:fiber, formulated using the same materials and methods as in Expt. 1. Source 2 blends consisted of 100:0 peat and 70:30 peat:coir, peat:wood, and peat:fiber blends formulated using peat and pine wood fiber consisting of a coarse Lithuanian sphagnum peatmoss (KlasmannDielmann) containing long fibers and little dust [von Post scale 1 to 2 (Puustjarvi and Robertson, 1975)] and scots pine (Pinus sylvestris) wood fiber (GreenFibre; Klasmann-Dielmann), respectively. Source 2 substrates used the same hammer-milled pine wood and coconut coir as in Expt. 1. Additional wetting agent (PsiMatric; Aquatrols) was added at $0.15 \mathrm{~mL} \cdot \mathrm{L}^{-1}$ of substrate.
On 11 May 2017, vegetatively propagated cuttings of 'Supertunia Vista Bubblegum' petunia in 128cell trays were received from a commercial propagator (Pleasant View Gardens) and transplanted into 8inch-diameter plastic azalea containers (Poppelmann Plastics US) filled with each treatment blend, with one plant per container. Eight replicates per substrate blend were arranged on greenhouse benches using a randomized complete block design with eight blocks. Each block was a separate greenhouse bench, and all benches were located within the same greenhouse. Initial substrate $\mathrm{pH}$ and $\mathrm{EC}$ was measured in each replicate using the pourthrough method described by Wright (1986).

Plants were fertilized at transplant and at each subsequent irrigation event using the same commercial water-soluble fertilizer described in Expt. 1, but at $250 \mathrm{ppm} \mathrm{N}$. Plants were irrigated using the same methods described in Expt. 1, and containers had plastic saucers underneath to collect leachate for reabsorption.

END-OF-PRODUCTION DATA COLLECTION. Data were collected 42 $\mathrm{d}$ after transplant on 22 June 2017 for the end-of-production. Leaf SPAD chlorophyll index, flower number per plant, plant height and width, and substrate $\mathrm{N}$ was measured for each replicate using the same methods described in Expt. 1. Four replicates per substrate treatment were destructively sampled by harvesting all plants in the first four adjacent blocks to measure shoot dry weight gain and percent $\mathrm{N}$ in dry shoot tissue. Similar to Expt. 1, shoot dry weight was collected on 20 extra petunia transplants harvested at the start of the experiment. Total shoot dry weight gain was calculated by subtracting the average shoot dry weight per petunia transplant from the total shoot dry weight per replicate at the end-of-the-consumer phase. Percent $\mathrm{N}$ in dry shoot tissue was also measured using the persulfate digestion method from Expt. 1 . Total $\mathrm{N}$ in shoot tissue was calculated by multiplying the percent $\mathrm{N}$ in dry shoot tissue by the total shoot dry weight per plant. Total accumulation of shoot tissue $\mathrm{N}$ was then calculated by subtracting the average shoot $\mathrm{N}$ weight per petunia transplant at the 
start of the experiment from the shoot $\mathrm{N}$ weight per replicate at the end-ofthe-production phase.

END-OF-CONSUMER DATA Collection. On 22 June 2017, the four remaining blocks and four replicates per substrate blend continued for an additional $42 \mathrm{~d}$ during a simulated retail consumer phase. Containers remained in the same greenhouse and were irrigated with de-ionized water (no fertilizer nutrients) following irrigation methods previously described for the production phase. On 3 Aug. 2017 , final data for the end-of-theconsumer phase were collected on the leaf SPAD chlorophyll index, flower number, plant height and width, shoot dry weight gain, percent shoot tissue $\mathrm{N}$, and total accumulated $\mathrm{N}$ in shoot tissue, as previously described in the last section for the end-of-production.

SubSTRATE PHYSICAL PROPERTIES AND NITROGEN IMMOBILIZATION. Samples of each substrate blend (not used for growing plants) were evaluated in the laboratory for percent air and water-filled pore space, dry bulk density, and potential to immobilize fertilizer N. Air and water-filled pore space and dry bulk density was measured for each substrate blend in 8-inch-diameter plastic azalea containers (Poppelmann Plastics US), using methods described by Bilderback (2009). Potential for $\mathrm{N}$ immobilization was measured on substrate without plants using the NDI procedure described by Handreck (1992a) and the VDLUFA procedure for testing $\mathrm{N}$ immobilization/mineralization in soilless substrates (VDLUFA, 2007).

Statistical analysis. Analysis of variance from PROC GLM in SAS (version 9.4) was used to evaluate substrate effects on plant height and width, leaf SPAD chlorophyll index, flower number, shoot dry weight gain, substrate $\mathrm{N}$, percent shoot tissue $\mathrm{N}$, and total accumulated $\mathrm{N}$ in shoot tissue at the end-of-production and end-ofconsumer phases.

Because multiple factors (the peat source, the wood fiber source and processing method, and the pre-plant nutrient charge) differed between substrate sources, the experimental design was not a simple balanced factorial where, for example, only peat source or wood fiber were varied. The source 1 and 2 substrates were therefore analyzed separately. Analysis of variance with PROC GLM was also used to evaluate substrate blend effects on nitrogen drawdown index measured using the Handreck (1992a) and VDLUFA (2007) methods. Mean separation used Tukey's HSD at $\alpha=0.05$.

\section{Results \\ Expt. 1: University of Florida greenhouse evaluation of substrate amendments with a single peat source}

END-OF-PRODUCTION PHASE. At the end-of-production phase, substrates differed in substrate $\mathrm{pH}[P \leq$ 0.01 (Table 1)], where $\mathrm{pH}$ was lowest for peat:coir (5.14) and greater for peat (5.60), peat:wood (5.59), and peat:fiber $(5.80)$. Initial $\mathrm{pH}$ at the beginning of the production phase was $($ mean \pm SD $) 5.29 \pm 0.15,6.04 \pm$ $0.07,5.85 \pm 0.10$, and $6.04 \pm 0.08$ for peat:coir, peat, peat:wood, and peat:fiber, respectively. Multiple factors interact to influence $\mathrm{pH}$ after blending substrates and during production, and include the substrate components, fertilizer $\mathrm{N}$ form, nutrient concentrations, water quality, and plant species (Argo and Fisher, 2002; Fisher et al., 2014). Interactions among these factors can be complex and likely contributed to differences in $\mathrm{pH}$ among the substrate blends. There was no significant difference among substrate treatments for EC, and EC remained within the sufficiency range ( 1.0 to $2.6 \mathrm{mS} \cdot \mathrm{cm}^{-1}$ using the pour-through method) recommended by Nelson (2011) for general bedding plants. The initial EC at the start-of-production phase was $1.33 \pm 0.68,1.63 \pm 0.21,1.03 \pm$ 0.24 , and $0.93 \pm 0.14 \mathrm{mS} \cdot \mathrm{cm}^{-1}$ for peat, peat:coir, peat:fiber, and peat:wood, respectively.

Flower number per plant was affected by substrate $[P \leq 0.05$ ( Table 1)], which ranged from 11 flowers/plant for peat:wood to 30 flowers/plant for peat:coir. As mentioned previously, plants were pruned after $21 \mathrm{~d}$ as a production strategy to promote a compact growth habit, which may have delayed flowering and reduced total flower number. Leaf SPAD chlorophyll index and plant height and width were unaffected by substrate in this experiment (Table 1). Plants exposed to all treatments had dark-green foliage and no visual symptoms of nutrient deficiency

Substrate affected substrate $\mathrm{N}$ concentration at the end-of-production $[P \leq 0.01$ (Table 1$)]$, where $\mathrm{N}$ was lowest for peat:coir (118.3 ppm $\mathrm{N})$ and greatest for peat $(201.1 \mathrm{ppm}$ $\mathrm{N})$ and peat:wood (182.8 ppm N), with peat:fiber as intermediate (170.7 ppm N) (Table 1). Nitrogen was within the range recommended for leachate $\mathrm{NO}_{3}-\mathrm{N}$ by Nelson (2011) for bedding plants (100 and $199 \mathrm{ppm}$ $\left.\mathrm{NO}_{3}-\mathrm{N}\right)$, and $\mathrm{NO}_{3}-\mathrm{N}$ averaged $90.6 \%$ of total substrate $\mathrm{N}$ across substrate blends in this experiment (remainder as $\mathrm{NH}_{4}-\mathrm{N}$, data not

Table 1. Effects of 100:0 (by volume) peat and 70:30 peat:coir, peat:wood, and peat:fiber substrate blends on substrate pH and electrical conductivity (EC), leaf SPAD chlorophyll index, flower number, plant height and width, substrate nitrogen (N) concentration, and percent shoot tissue $\mathrm{N}$ for petunia at the end-of-production phase for Expt. 1 .

\begin{tabular}{|c|c|c|c|c|c|c|c|c|}
\hline Substrate & $\begin{array}{c}\text { Substrate } \\
\text { pH }\end{array}$ & $\begin{array}{c}\text { Substrate EC } \\
\left(\mathrm{mS} \cdot \mathrm{cm}^{-1}\right)^{\mathrm{z}}\end{array}$ & $\begin{array}{c}\text { Leaf SPAD } \\
\text { chlorophyll } \\
\text { index }\end{array}$ & $\begin{array}{l}\text { Flowers } \\
\text { (no./ } \\
\text { plant) }\end{array}$ & $\begin{array}{l}\text { Width } \\
(\mathrm{cm})^{\mathrm{z}}\end{array}$ & $\begin{array}{c}\mathrm{Ht} \\
(\mathrm{cm})\end{array}$ & $\begin{array}{l}\text { Substrate } \\
\mathbf{N}(\text { ppm })^{z}\end{array}$ & $\begin{array}{c}\text { Tissue } \mathrm{N} \\
(\%)\end{array}$ \\
\hline Peat & $5.60 \mathrm{a}^{\mathrm{y}}$ & $2.15 \mathrm{a}$ & $49.0 \mathrm{a}$ & $25 \mathrm{ab}$ & $68.1 \mathrm{a}$ & $28.9 \mathrm{a}$ & $201.1 \mathrm{a}$ & $5.62 \mathrm{a}$ \\
\hline Peat:wood & $5.59 \mathrm{a}$ & $2.04 \mathrm{a}$ & $46.3 \mathrm{a}$ & $11 \mathrm{~b}$ & $67.7 \mathrm{a}$ & $28.5 \mathrm{a}$ & $182.8 \mathrm{a}$ & $5.32 \mathrm{a}$ \\
\hline \multirow[t]{2}{*}{ Peat:fiber } & $5.80 \mathrm{a}$ & $2.00 \mathrm{a}$ & $48.3 \mathrm{a}$ & $25 \mathrm{ab}$ & $67.4 \mathrm{a}$ & $29.3 \mathrm{a}$ & $170.7 \mathrm{ab}$ & $5.31 \mathrm{a}$ \\
\hline & $* *$ & NS & NS & * & NS & NS & $* *$ & NS \\
\hline
\end{tabular}

${ }^{\mathrm{z}} 1 \mathrm{mS} \cdot \mathrm{cm}^{-1}=1 \mathrm{mmho} / \mathrm{cm}, 1 \mathrm{~cm}=0.3937 \mathrm{inch}, 1 \mathrm{ppm}=1 \mathrm{mg} \cdot \mathrm{L}^{-1}$.

${ }^{y}$ Data represent least square means of eight replicates, and mean separation used Tukey's honestly significant difference at $\alpha=0.05$. Means with the same lowercase letter are not significantly different. Ns, ${ }^{*},{ }^{*}$ Nonsignificant or significant at $P \leq 0.05$ or 0.01 , respectively. 
Table 2. Effects of 100:0 (by volume) peat and 70:30 peat:coir, peat:wood, and peat:fiber substrate blends on substrate pH and electrical conductivity (EC), leaf SPAD chlorophyll index, flower number, plant height and width, substrate nitrogen (N) concentration, percent $\mathrm{N}$ in dry shoot tissue, and shoot dry weight gain for petunia at the end-of-consumer phase for Expt. 1.

\begin{tabular}{|c|c|c|c|c|c|c|c|c|c|}
\hline Substrate & $\begin{array}{c}\text { Substrate- } \\
\text { pH }\end{array}$ & $\begin{array}{c}\text { Substrate- } \\
\text { EC } \\
\left(\mathrm{mS} \cdot \mathrm{cm}^{-1}\right)^{\mathrm{z}}\end{array}$ & $\begin{array}{c}\text { Leaf SPAD } \\
\text { chlorophyll } \\
\text { index }\end{array}$ & $\begin{array}{c}\text { Flowers } \\
\text { (no./plant) }\end{array}$ & $\begin{array}{l}\text { Width } \\
(\mathrm{cm})^{\mathrm{z}}\end{array}$ & $\mathrm{Ht}(\mathrm{cm})$ & $\begin{array}{c}\text { Substrate N } \\
(\mathrm{ppm})^{\mathrm{z}}\end{array}$ & $\begin{array}{c}\text { Tissue } \mathrm{N} \\
(\%) \\
\end{array}$ & $\begin{array}{l}\text { Shoot dry } \\
\text { wt gain } \\
\text { (g/plant })^{z}\end{array}$ \\
\hline Peat & $6.22 \mathrm{a}^{\mathrm{y}}$ & $0.61 \mathrm{~b}$ & $30.8 \mathrm{a}$ & $134 \mathrm{~b}$ & $128.8 \mathrm{a}$ & $34.9 \mathrm{a}$ & $0.62 \mathrm{a}$ & $2.18 \mathrm{a}$ & $75.1 \mathrm{bc}$ \\
\hline Peat:wood & $6.02 \mathrm{a}$ & $0.64 \mathrm{ab}$ & $26.8 \mathrm{a}$ & $127 \mathrm{~b}$ & $119.2 \mathrm{a}$ & $38.8 \mathrm{a}$ & $0.58 \mathrm{a}$ & $2.12 \mathrm{a}$ & $72.5 \mathrm{c}$ \\
\hline Peat:fiber & $\begin{array}{c}6.13 \mathrm{a} \\
* *\end{array}$ & $\begin{array}{c}1.17 \mathrm{a} \\
*\end{array}$ & $\begin{array}{c}35.4 \text { a } \\
\text { NS }\end{array}$ & $\begin{array}{c}133 \mathrm{~b} \\
* *\end{array}$ & $\begin{array}{c}122.2 \mathrm{a} \\
\mathrm{NS}\end{array}$ & $\begin{array}{c}35.7 \text { a } \\
\text { NS }\end{array}$ & $\begin{array}{c}0.48 \text { a } \\
\text { NS }\end{array}$ & $\underset{* * *}{2.16 \mathrm{a}}$ & $\begin{array}{c}79.6 \mathrm{ab} \\
* *\end{array}$ \\
\hline
\end{tabular}

${ }^{\mathrm{z}} 1 \mathrm{mS} \cdot \mathrm{cm}^{-1}=1 \mathrm{mmho} / \mathrm{cm}, 1 \mathrm{~cm}=0.3937 \mathrm{inch}, 1 \mathrm{ppm}=1 \mathrm{mg} \cdot \mathrm{L}^{-1}, 1 \mathrm{~g}=0.0353 \mathrm{oz}$.

y Data represent least square means of eight replicates, and mean separation used Tukey's honestly significant difference at $\alpha=0.05$. Means with the same lowercase letter are not significantly different. Ns, ${ }^{*}, * * * *$ Nonsignificant or significant at $P \leq 0.05,0.01$, or 0.0001 , respectively.

Table 3. Effects of 100:0 (by volume) peat and 70:30 peat:coir, peat:wood, and peat:fiber substrate blends on leaf SPAD chlorophyll index, flower number, plant height and width, shoot dry weight, substrate nitrogen (N) concentration, and percent $\mathrm{N}$ in dry shoot tissue of petunia at the end-of-production phase for Expt. 2. Source 1 and 2 substrate blends differed in the source of peat and wood fiber. Source 1 substrates contained Latvian sphagnum peat and expanded European pine wood fiber. Source 2 substrates contained Lithuanian sphagnum peatmoss and scots pine wood fiber.

\begin{tabular}{|c|c|c|c|c|c|c|c|c|}
\hline & Substrate & $\begin{array}{c}\text { Leaf SPAD } \\
\text { chlorophyll index }\end{array}$ & $\begin{array}{c}\text { Flowers } \\
\text { (no./plant) }\end{array}$ & Width $(\mathrm{cm})^{\mathrm{z}}$ & $\mathrm{Ht}(\mathrm{cm})$ & $\begin{array}{l}\text { Shoot dry wt gain } \\
(\mathrm{g} / \text { plant })^{\mathrm{z}}\end{array}$ & $\begin{array}{c}\text { Substrate } N \\
(\mathrm{ppm})^{\mathrm{z}}\end{array}$ & Tissue N (\%) \\
\hline \multirow[t]{4}{*}{ Source 1} & Peat & $48.7 \mathrm{a}^{\mathrm{y}}$ & $86 a$ & $58.6 \mathrm{a}$ & $15.6 \mathrm{a}$ & $27.4 \mathrm{a}$ & $57.9 \mathrm{ab}$ & $4.41 \mathrm{a}$ \\
\hline & Peat:wood & $45.8 \mathrm{ab}$ & $92 \mathrm{a}$ & $57.9 \mathrm{a}$ & $15.7 \mathrm{a}$ & $29.1 \mathrm{a}$ & $53.5 \mathrm{~b}$ & $4.08 \mathrm{a}$ \\
\hline & Peat:fiber & $44.4 \mathrm{~b}$ & $45 \mathrm{~b}$ & $47.6 \mathrm{~b}$ & $13.2 \mathrm{~b}$ & $18.4 \mathrm{~b}$ & $59.4 \mathrm{ab}$ & $4.17 \mathrm{a}$ \\
\hline & & * & $* * *$ & * & * & ** & * & NS \\
\hline & Peat:wood & $50.8 \mathrm{a}$ & $53 \mathrm{~b}$ & $52.9 \mathrm{~b}$ & $15.6 \mathrm{a}$ & $20.0 \mathrm{ab}$ & $62.2 \mathrm{a}$ & $4.45 \mathrm{ab}$ \\
\hline & Peat:fiber & $49.7 \mathrm{a}$ & $47 \mathrm{~b}$ & $47.5 \mathrm{~b}$ & $13.7 \mathrm{a}$ & $16.9 \mathrm{~b}$ & $69.8 \mathrm{a}$ & $4.34 \mathrm{bc}$ \\
\hline & & NS & $* *$ & $* *$ & NS & $* *$ & NS & $\star *$ \\
\hline
\end{tabular}

${ }^{\mathrm{z}} 1 \mathrm{~cm}=0.3937$ inch, $1 \mathrm{~g}=0.0353 \mathrm{oz}, 1 \mathrm{ppm}=1 \mathrm{mg} \cdot \mathrm{L}^{-1}$.

${ }^{\mathrm{y}}$ Data represent least square means of four replicates, and mean separation used Tukey's honestly significant difference at $\alpha 0.05$. Means with the same lowercase letter are not significantly different. NS, ${ }^{*},{ }^{*},{ }^{* *}$ Nonsignificant or significant at $P \leq 0.05,0.01$, or 0.0001 , respectively.

shown). Percent $\mathrm{N}$ in dry shoot tissue was unaffected by substrate and was within the optimal range recommended for petunia $(3.85 \%$ to $7.60 \% \mathrm{~N})$ by Mills and Jones (1996) for all substrates (Table 1 ).

END-OF-CONSUMER PHASE. Similar to results at the end-ofproduction, substrate $\mathrm{pH}$ was lower at the end-of-consumer phase for peat:coir (5.49) compared with peat (6.22), peat:wood (6.02), and peat:fiber (6.13) $[P \leq 0.01$ (Table 2)]. Substrate EC differed among substrates $[P \leq 0.05$ (Table 2$)]$, which ranged from $0.61 \mathrm{mS} \cdot \mathrm{cm}^{-1}$ for peat to $1.17 \mathrm{mS} \cdot \mathrm{cm}^{-1}$ for peat:fiber. Substrate EC values were either near or below the lower limit of the sufficiency range (1.0 to $2.6 \mathrm{mS} \cdot \mathrm{cm}^{-1}$ ) recommended by Nelson (2011), indicating depletion of root-zone nutrients after 61 $\mathrm{d}$ of clear-water irrigation.

Substrate affected flower number at the end-of-consumer phase
$[P \leq 0.01$ (Table 2$)]$, which was lowest for peat (134 flowers/plant), peat:wood (127 flowers/plant), and peat:fiber (133 flowers/plant) and greatest for peat:coir (175 flowers/ plant). Substrate also affected final shoot dry weight $[P \leq 0.01$ (Table $2)$, which ranged from $72.5 \mathrm{~g}$ for peat:wood to $85.8 \mathrm{~g}$ for peat:coir. Leaf SPAD chlorophyll index and plant height and width were not influenced by substrate at the end of the experiment (Table 2).

Percent $\mathrm{N}$ in dry shoot tissue differed among substrates at the end-of-consumer phase $[P \leq 0.001$ (Table 2)], and it was greatest for peat $(2.18 \% \mathrm{~N})$, peat:wood $(2.12 \% \mathrm{~N})$, and peat:fiber $(2.16 \% \mathrm{~N})$, and it was lowest for peat:coir $(1.78 \% \mathrm{~N})$. However, shoot tissue $\mathrm{N}$ for each substrate was below the sufficiency range recommended for petunia $(3.85 \%$ to $7.60 \% \mathrm{~N}$ ) by Mills and Jones (1996). Substrate N was unaffected by substrate blend (Table 2), and substrate $\mathrm{N}$ was near depleted by the end-of-consumer phase. All plants developed general symptoms of leaf chlorosis and yellowing, and symptoms matched descriptions of $\mathrm{N}$ deficiency reported for petunia by Gibson et al. (2007). Shoot tissue was also analyzed for other plant essential elements, which were also below the recommended values for petunia [Gibson et al., 2007; Mills and Jones, 1996 (data not shown for essential elements other than $\mathrm{N}$ )].

\section{Expt. 2: University of New Hampshire greenhouse evaluation of substrate amendments with two peat sources}

END-OF-PRODUCTION PHASE. Like the results from Expt. 1, all petunia plants had dark-green foliage at the end-of-production phase. Leaf SPAD chlorophyll index differed 
between source 1 substrates $[P \leq 0.05$ (Table 3)], but not between source 2 substrates. Leaf SPAD chlorophyll index with source 1 substrates was lowest for plants grown in peat:fiber (44.4) and greatest for peat (48.7), with peat:coir (47.9) and peat:wood (45.8) as intermediate (Table 3 ).

Substrate $\mathrm{pH}$ was not significantly different among substrate treatments after the production phase (data not shown), and ranged from 6.53 (peat:wood) to 6.58 (peat:coir) with source 1 substrates and from 6.28 (peat:fiber) to 6.30 (peat:wood) with source 2 substrates. Initial substrate $\mathrm{pH}$ at the beginning of the experiment for peat, peat:coir, peat:wood, and peat:fiber was (mean \pm SD) $6.40 \pm 0.26,6.10 \pm 0.06,6.40 \pm$ 0.17 , and $6.38 \pm 0.14$ for source 1 substrates and $5.98 \pm 0.32,5.74 \pm$ $0.13,5.80 \pm 0.12,5.30 \pm 0.22$ for source 2 substrates, respectively. Substrate EC after the production phase ranged from $1.52 \mathrm{mS} \cdot \mathrm{cm}^{-1}$ (peat:fiber) to $1.94 \mathrm{mS} \cdot \mathrm{cm}^{-1}$ (peat:coir) with source 1 substrates and from $3.15 \mathrm{mS} \cdot \mathrm{cm}^{-1}$ (peat:wood) to 4.43 $\mathrm{mS} \cdot \mathrm{cm}^{-1}$ (peat) with source $2 \mathrm{sub}$ strates. Initial substrate EC at the beginning of the experiment was $0.48 \pm 0.21,1.20 \pm 0.24,0.60 \pm$ 0.28 , and $0.40 \pm 0.35 \mathrm{mS} \cdot \mathrm{cm}^{-1}$ for source 1 substrates and $1.69 \pm 0.35$, $1.85 \pm 0.57,1.31 \pm 0.28$, and $1.32 \pm$ $0.24 \mathrm{mS} \cdot \mathrm{cm}^{-1}$ for source 2 substrates, respectively.

Substrate blend affected flower number per plant with both source 1 substrates $(P \leq 0.001)$ and source 2 substrates $[P \leq 0.01$ (Table 3)]. Flower number ranged from 45 flowers/plant for peat:fiber to 92 flowers/plant for peat:wood with source 1 substrates, and from 47 flowers/plant for peat:fiber to 77 flowers/plant for peat with source 2 substrates. Plant width was lowest for peat:fiber with source 1 substrates and for peat:fiber and peat:wood with source 2 substrates $[P \leq 0.05$ (Table $3)$, resulting in a more compact growth habit. Plant height was lowest for peat:fiber $(13.2 \mathrm{~cm})$ with source 1 substrates $[P \leq 0.05$ (Table 3 ) $]$, and it was unaffected by source 2 substrates.

Shoot dry weight gain was affected by substrate blend and was consistently lowest for peat:fiber $[P$ $\leq 0.01$ (Table 3 )]. Shoot dry weight gain ranged from $18.4 \mathrm{~g}$ for peat:fiber to $29.1 \mathrm{~g}$ for peat:wood with source 1 substrates, and from $16.9 \mathrm{~g}$ for peat:fiber to $25.3 \mathrm{~g}$ for peat with source 2 substrates (Table 3). Amending peat with coir (peat:coir) and hammermilled pine wood (peat:wood) did not influence dry weight gain compared with $100 \%$ peat. Previous trials have evaluated hammer-milled pine wood chips incorporated in peatmoss at rates of $30 \%$ and also reported no difference in shoot growth of zinnia (Zinnia elegans) and marigold (Tagetes patula) when grown at similar $\mathrm{N}$ rates (Owen et al., 2016). Shoot dry weight gain was positively correlated with flower number per replicate with both source 1 and 2 substrates $[r>0.90$ (data not shown)], indicating that plants with greater shoot growth also had a greater number of flowers.

Substrate N concentration was affected by substrate blend with source 1 substrates $[P \leq 0.05$ (Table $3)$ ], but not with source 2 substrates. Substrate N ranged from 53.5 ppm N for peat:wood to $60.9 \mathrm{ppm} \mathrm{N}$ for peat:coir with source 1 substrates, and from 62.2 ppm $\mathrm{N}$ for peat:wood to $76.3 \mathrm{ppm} \mathrm{N}$ for peat:coir with source 2 substrates (Table 3 ) and were within the acceptable range for $\mathrm{NO}_{3}-\mathrm{N}$ (40 to 99 ppm $\mathrm{NO}_{3}-\mathrm{N}$ ) recommended by Nelson (2011) for bedding plants. Shoot tissue $\mathrm{N}$ concentration differed between substrate blends with source 2 substrates [ $P \leq$ 0.01 (Table 3 )], but not with source 1 substrates. Percent shoot tissue $\mathrm{N}$ was within the optimal sufficiency range $(3.85 \%$ to $7.60 \% \mathrm{~N})$ recommended for petunia by Mills and Jones (1996) for all substrate treatments.

Source 1 and 2 substrates affected total accumulation of $\mathrm{N}$ in shoot tissue (which was calculated from the shoot dry weight gain multiplied by the tissue $\mathrm{N}$ concentration shown in Table $3[P \leq 0.05$ (Fig. lA)]. The $\mathrm{N}$ accumulation was consistently lowest for peat:fiber (776 and $735 \mathrm{mg} \mathrm{N}$, respectively). Nitrogen accumulation with source 1 substrates was greater for peat (1208 mg $\mathrm{N})$, peat:coir (1144 mg N), and peat:wood (1186 mg N) compared with peat:fiber. With source $2, \mathrm{~N}$ accumulation was greater for peat $[1216 \mathrm{mg}$ N (Fig. 1A)] compared with peat:fiber. Nitrogen uptake efficiency could be estimated as the amount of $\mathrm{N}$ in shoot tissue divided by the amount of $\mathrm{N}$ applied from the water-soluble fertilizer per replicate, which ranged from $59.7 \%$ (peat:fiber) to $92.9 \%$ (peat) with source 1 substrates and from $56.6 \%$ (peat:fiber) to $93.6 \%$ (peat) with source 2 blends (data not shown).

END-OF-CONSUMER PHASE. Similar to plants in Expt. 1, all plants developed symptoms of leaf chlorosis and yellowing by the end-of-the consumer phase and appeared $\mathrm{N}$ deficient following $42 \mathrm{~d}$ of clear-water irrigation. Leaf SPAD chlorophyll index was affected by substrate blend with source 2 substrates $[P \leq 0.05$ (Table 4)], but not with source 1 substrates. However, leaf SPAD chlorophyll index values for plants grown in all substrate treatments were below 35 (Table 4), which was the approximate leaf SPAD value threshold where visual symptoms of chlorosis were first observed. Flower number and plant height and width were unaffected by substrate blend with source 1 or source 2 substrates (Table $4)$.

Substrate affected shoot dry weight gain at the end-of-consumer phase $[P \leq 0.01$ (Table 4 )], and trends were consistent between source 1 and 2 substrates. Shown in Table 4, shoot dry weight gain was lowest for peat:wood (49.9 and $44.0 \mathrm{~g}$ ) and greatest for peat $(68.2$ and $57.0 \mathrm{~g})$ and peat:coir $(65.8$ and $53.9 \mathrm{~g})$, with peat:fiber as intermediate (62.0 and $48.3 \mathrm{~g}$ ) (Table 4 ) with source 1 and source 2 substrates, respectively.

Substrate $\mathrm{N}$ was unaffected by source 1 or source 2 substrates (Table 4 ) and was near zero at the end-ofconsumer phase (consistent with Expt. 1). Percent shoot tissue N values were also below the optimal range $(3.85 \%$ to $7.60 \% \mathrm{~N})$ reported for petunia by Mills and Jones (1996). Substrate affected accumulation of $\mathrm{N}$ in shoot tissue for source $\mathrm{l}$ and 2 substrates $[P \leq 0.05$ (Fig. 1B)], where $\mathrm{N}$ accumulation was consistently lowest for peat:wood (849 and $886 \mathrm{mg} \mathrm{N}$ ) and greatest for peat (1358 and $1249 \mathrm{mg} \mathrm{N}$ ).

SUBSTRATE PHYSICAL PROPERTIES AND NITROGEN IMMOBILIZATION. Substrate physical properties differed among source 1 substrates $[P \leq 0.05$ (Table 5 )], but not source 2 substrates. Air-filled porosity was lowest for peat:coir $(29.9 \%)$ and greatest for peat:wood $(37.4 \%)$, whereas peat $(34.3 \%)$ and peat:fiber $(34.2 \%)$ were 

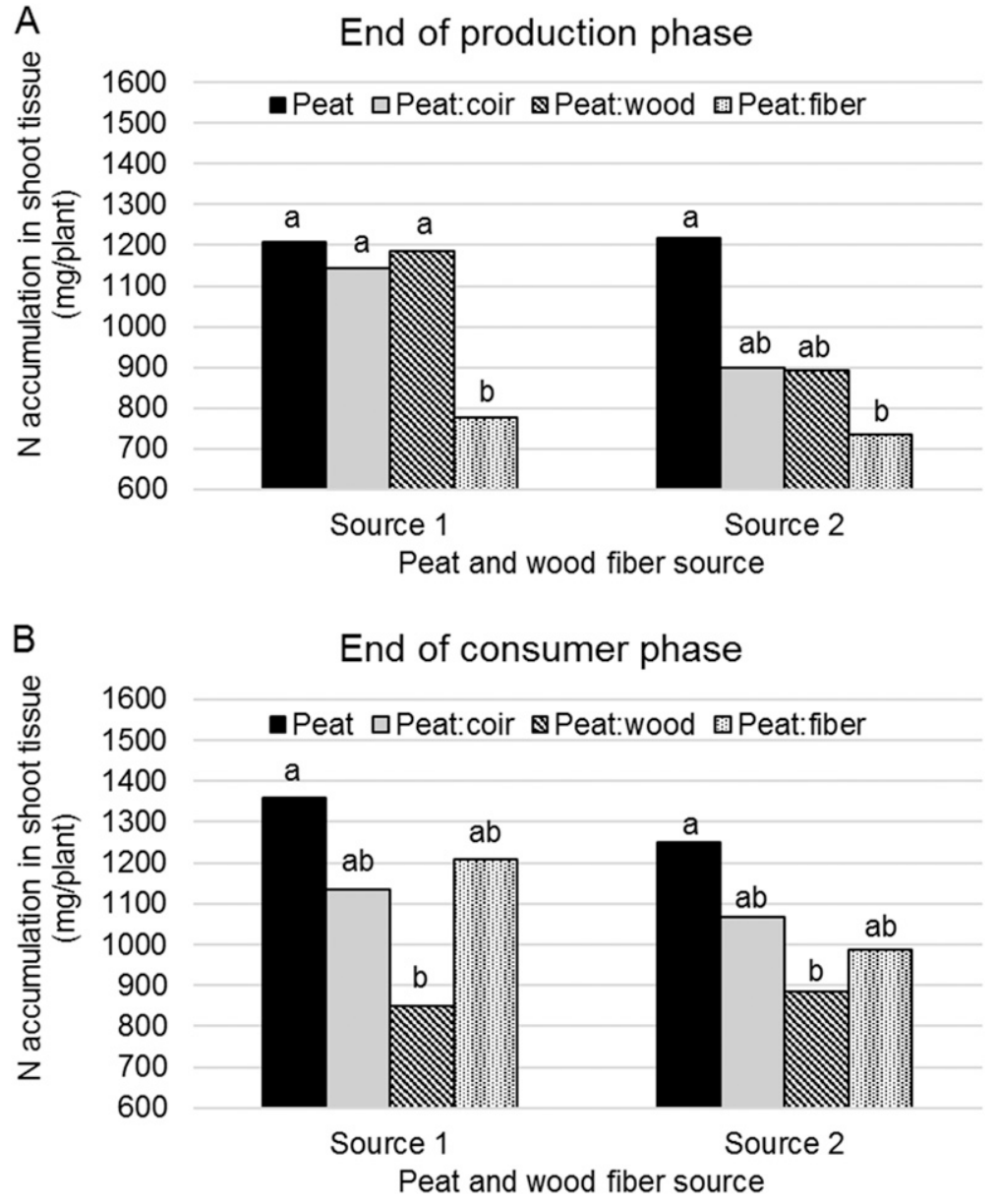

Fig. 1. Effects of 100:0 (by volume) peat and 70:30 peat:coir, peat:wood, and peat:fiber substrate blends on milligrams of nitrogen $(N)$ accumulated per plant in shoots of petunia at end-of-production (Fig. 1A) and end-of-consumer (Fig. 1B) phases during Expt. 2. Source 1 and 2 substrate blends differed in the source of peat and wood fiber. Source 1 substrates contained Latvian sphagnum peat and expanded European pine wood fiber. Source 2 substrates contained Lithuanian sphagnum peatmoss and scots pine wood fiber. Data represent least square means of four replicates, and mean separation used Tukey's honestly significant difference at $\alpha=$ 0.05. Bars with the same lowercase letter are not significantly different. Coefficient of variation for source 1 and 2 substrate blends was $20.6 \%$ and $24.4 \%$ at the end-ofproduction phase and $20.9 \%$ and $\mathbf{1 8 . 8 \%}$ at the end-of-consumer phase, respectively; $1 \mathrm{mg}=3.5274 \times 10^{-5} \mathrm{oz}$.

intermediate with source 1 substrates. In contrast, water-filled pore space was lowest with peat:wood $(48.0 \%)$ and greatest with peat:coir $(58.6 \%)$. Dry bulk density was also greater for peat:wood (103.4 $\mathrm{g} \cdot \mathrm{L}^{-1}$ substrate) and lower for the remaining source 1 substrate blends. Overall, amending peat with pine wood fiber did not influence the physical properties measured in this study with source 1 or 2 substrates.

Amending peat with pine wood fiber, hammer-milled pine wood, and coconut coir did not have a significant effect on $\mathrm{N}$ immobilization in this study. Nitrogen drawdown index values of less than 1 , greater than 1 , and equal to $\mathrm{l}$ would indicate $\mathrm{N}$ immobilization ( $\mathrm{N}$ drawdown), $\mathrm{N}$ mineralization ( $\mathrm{N}$ release), and no $\mathrm{N}$ immobilization/mineralization effect, respectively. Each substrate blend had NDI values not statistically different from 1 for both the Handreck (1992a) and VDLUFA (2007) methods. Nitrogen index values ranged from 0.90 (peat:coir) to 1.18 (peat:fiber) with source 1 substrates and from 0.86 (peat) to 0.99 (peat:fiber) with source 2 substrates using the Handreck (1992) method, and from 0.90 (peat:wood) to 1.05 (peat) with source 1 substrates and from 0.97 (peat:wood) to 0.99 (peat) with source 2 substrates using the VDLUFA method (data not shown).

\section{Discussion}

Results indicate that peat-based substrates amended with $30 \%$ of either pine wood fiber or hammermilled pine wood were suitable for the production of containerized petunia. In Expt. 1, amending peat with pine wood fiber had no effect on leaf SPAD chlorophyll index, plant growth, height and width, substrate and shoot tissue $\mathrm{N}$ at the endof-production, although peat with hammer-milled pine wood had the lowest flower number (Table 1 ). Amending peat with wood fiber reduced flower number, plant height and width, shoot dry weight gain, and $\mathrm{N}$ accumulation compared with $100 \%$ peat in Expt. 2 (Table 3, Fig. 1A), although peat:fiber substrates still had dark-green foliage and adequate flowering as evidenced by relatively high leaf SPAD chlorophyll index values $(\geq 44.4)$ and flower number per plant ( $\geq 45$ flowers / plant). With constant fertigation in a commercial greenhouse operation, it would be straightforward to increase applied fertilizer level if needed to compensate for $\mathrm{N}$ immobilization when producing petunia using wood products.

During the consumer phase, when no fertigation occurred, there was evidence of reduced plant performance with peat:wood. Substrate N concentration was depleted in both Expts. 1 and 2 during the consumer phase with all substrate blends following several weeks of clear-water irrigation, resulting in leaf chlorosis and symptoms of $\mathrm{N}$ deficiency (Tables 2 and 4). Growing plants in peat:wood resulted in the lowest shoot dry weight during the consumer phase in Expts. 1 and 2 (Table 2). Previous research has shown that without a residual fertilizer charge supplied during production, bedding plant growth and quality can decline rapidly for the consumer (Argo and Biernbaum, 1993; Armitage, 1993; de Oliviera et al., 2016). One approach would be to top-dress additional fertilizer at the end-of-the-production phase to compensate for $\mathrm{N}$ immobilization by hammer-milled wood (and to improve performance with all substrates). 
Table 4. Effects of 100:0 (by volume) peat and 70:30 peat:coir, peat:wood, and peat:fiber substrate blends on leaf SPAD chlorophyll index, flower number, plant height and width, shoot dry weight gain, substrate nitrogen $(\mathrm{N})$ concentration, and percent $\mathrm{N}$ in dry shoot tissue of petunia at the end-of-consumer phase for Expt. 2 . Source 1 and 2 substrate blends differed in the source of peat and wood fiber. Source 1 substrates contained Latvian sphagnum peat and expanded European pine wood fiber. Source 2 substrates contained Lithuanian sphagnum peatmoss and scots pine wood fiber.

\begin{tabular}{|c|c|c|c|c|c|c|c|c|}
\hline & Substrate & $\begin{array}{l}\text { Leaf SPAD } \\
\text { chlorophyll } \\
\text { index }\end{array}$ & $\begin{array}{c}\text { Flowers (no./ } \\
\text { plant) }\end{array}$ & $\begin{array}{l}\text { Width } \\
(\mathrm{cm})^{\mathrm{z}}\end{array}$ & $\begin{array}{c}\mathrm{Ht} \\
(\mathrm{cm})\end{array}$ & $\begin{array}{l}\text { Shoot dry wt gain } \\
(\mathrm{g} / \text { plant })^{\mathrm{z}}\end{array}$ & $\begin{array}{c}\text { Substrate } N \\
(\mathrm{ppm})^{\mathrm{z}}\end{array}$ & $\begin{array}{c}\text { Tissue } \mathrm{N} \\
(\%)\end{array}$ \\
\hline \multirow[t]{3}{*}{ Source 1} & Peat & $28.2 \mathrm{a}^{\mathrm{y}}$ & $141 \mathrm{a}$ & 88.9 a & $22.6 \mathrm{a}$ & $68.2 \mathrm{a}$ & $0.42 \mathrm{a}$ & $1.99 \mathrm{a}$ \\
\hline & Peat:wood & $27.2 \mathrm{a}$ & $115 \mathrm{a}$ & $83.8 \mathrm{a}$ & $24.5 \mathrm{a}$ & $49.9 \mathrm{~b}$ & $0.46 \mathrm{a}$ & $1.71 \mathrm{a}$ \\
\hline & Peat:fiber & $29.7 \mathrm{a}$ & $140 \mathrm{a}$ & $85.1 \mathrm{a}$ & $25.1 \mathrm{a}$ & $62.0 \mathrm{ab}$ & $0.46 \mathrm{a}$ & $1.95 \mathrm{a}$ \\
\hline & Peat:coir & $32.2 \mathrm{a}$ & $115 a$ & $90.8 \mathrm{a}$ & $25.4 \mathrm{a}$ & $53.9 \mathrm{a}$ & $0.31 \mathrm{a}$ & $1.98 \mathrm{a}$ \\
\hline & Peat:wood & $23.8 \mathrm{~b}$ & $99 a$ & $90.2 \mathrm{a}$ & $23.5 \mathrm{a}$ & $44.0 \mathrm{~b}$ & $0.19 \mathrm{a}$ & $2.06 \mathrm{a}$ \\
\hline & Peat:fiber & $25.8 \mathrm{ab}$ & 99 a & $84.5 \mathrm{a}$ & $21.9 \mathrm{a}$ & $48.3 \mathrm{ab}$ & $0.20 \mathrm{a}$ & $2.04 \mathrm{a}$ \\
\hline & & * & NS & NS & NS & $* *$ & NS & NS \\
\hline
\end{tabular}

${ }^{\mathrm{z}} 1 \mathrm{~cm}=0.3937$ inch, $1 \mathrm{~g}=0.0353 \mathrm{oz}, 1 \mathrm{ppm}=1 \mathrm{mg} \cdot \mathrm{L}^{-1}$.

${ }^{y}$ Data represent least square means of four replicates, and mean separation used Tukey's honestly significant difference at $\alpha=0.05$. Means with the same lowercase letter are not significantly different. NS, ${ }^{*},{ }^{*}$ Nonsignificant or significant at $P \leq 0.05$ or 0.01 , respectively.

Table 5. Percent total pore space, percent air and water-filled pore space and dry bulk density for 100:0 (by volume) peat and 70:30 peat:coir, peat:wood, and peat:fiber substrate blends. Source 1 and 2 substrate blends differed in the source of peat and wood fiber. Source 1 substrates contained Latvian sphagnum peat and expanded European pine wood fiber. Source 2 substrates contained Lithuanian sphagnum peatmoss and scots pine wood fiber.

\begin{tabular}{|c|c|c|c|c|c|}
\hline & Substrate & $\begin{array}{l}\text { Total pore } \\
\text { space }(\%)\end{array}$ & $\begin{array}{l}\text { Air-filled pore } \\
\text { space }(\%)\end{array}$ & $\begin{array}{l}\text { Water-filled pore } \\
\text { space }(\%)\end{array}$ & $\begin{array}{c}\text { Dry bulk } \\
\text { density }\left(\mathrm{g} \cdot \mathrm{L}^{-1}\right)^{\mathrm{z}}\end{array}$ \\
\hline \multirow[t]{4}{*}{ Source 1} & Peat & $87.0 \mathrm{a}^{\mathrm{y}}$ & $34.3 \mathrm{~b}$ & $52.7 \mathrm{~b}$ & $96.8 \mathrm{~b}$ \\
\hline & Peat:wood & $85.4 \mathrm{a}$ & $37.4 \mathrm{a}$ & $48.0 \mathrm{c}$ & $103.4 \mathrm{a}$ \\
\hline & Peat:fiber & $86.4 \mathrm{a}$ & $34.2 \mathrm{~b}$ & $52.2 \mathrm{~b}$ & $96.8 \mathrm{~b}$ \\
\hline & & NS & $* *$ & $* * *$ & * \\
\hline \multirow{3}{*}{ Source 2} & Peat:wood & $84.6 \mathrm{a}$ & $31.1 \mathrm{a}$ & $53.5 \mathrm{a}$ & $88.0 \mathrm{a}$ \\
\hline & Peat:fiber & 84.9 a & $28.4 \mathrm{a}$ & $56.6 \mathrm{a}$ & $89.1 \mathrm{a}$ \\
\hline & & NS & NS & NS & NS \\
\hline
\end{tabular}

${ }^{\mathrm{z}} 1 \mathrm{~g} \cdot \mathrm{L}^{-1}=0.1 \%$.

${ }^{y}$ Data represent least square means of three replicates; and mean separation used Tukey's honestly significant difference at $\alpha=0.05$. Means with the same lowercase letter are not significantly different. Ns, ${ }^{*},{ }^{*},{ }^{* *}$ Nonsignificant or significant at $P \leq 0.05,0.01$, or 0.0001 , respectively.

Amending peat with coir decreased air porosity, and hammermilled pine wood increased air porosity, with source 1 substrates compared with peat, but this method had no effect on source 2 substrates (Table 5). Given that the same pine wood and coir was used for sources 1 and 2 , the differing effects on porosity may have resulted from differences in particle size and distribution between peat sources. Sphagnum peatmoss and pine wood fiber are both fibrous materials with similar texture (Maher et al., 2008), which may explain why amending peat with $30 \%$ wood fiber had no effect on substrate physical properties in Table 1.
The laboratory methods used in this study did not indicate $\mathrm{N}$ immobilization from wood products, and alternative methods may be needed. Biological respiration measured as the consumption of oxygen $\left(\mathrm{O}_{2}\right)$ or production of carbon dioxide $\left(\mathrm{CO}_{2}\right)$ is often used to determine the stability of organic soilless substrates (Blok et al., 2008). Bugbee and Heins (2018) tested seven types of sawdust and shredded wood materials and found that biological oxygen demand was 2-fold greater compared with sphagnum peat, and demand increased another 2 -fold when materials were incubated with $\mathrm{N}$. Jackson et al. (2009) found similar trends measuring $\mathrm{CO}_{2}$ production, where $\mathrm{CO}_{2}$ efflux was greater in pine treebased compared with peat-based substrate and was positively correlated with applied fertilizer N. Biological activity would also increase with easily degradable organic materials and during $\mathrm{N}$ mineralization ( $\mathrm{N}$ release) from composts, and would need to be accounted for when using $\mathrm{O}_{2}$ consumption $/ \mathrm{CO}_{2}$ efflux to evaluate $\mathrm{N}$ immobilization in wood substrates.

Shoot dry weight gain and accumulation of $\mathrm{N}$ in shoot tissue are useful methods to evaluate $\mathrm{N}$ availability in wood substrates and resulting effects on plant growth. In the second experiment, shoot dry weight 
gain and accumulation of shoot tissue $\mathrm{N}$ was greatest with $100 \%$ peat at the end-of-production and end-ofconsumer phases (Tables 4 and 5, Fig. 1). In contrast, shoot dry weight gain and $\mathrm{N}$ accumulation were lowest for peat:fiber at the end-of-production phase and for peat:wood at the end-of-consumer phase (Tables 4 and 5, Fig. 1). Decreased shoot growth for petunia grown in peat:fiber was also correlated with decreased flower number and plant height and width (Table 3), which are other indicators of plant performance and quality. Horticultural operations often analyze dried shoot tissue for nutrient concentrations when monitoring crop fertility, and therefore already collect the measurements needed to calculate shoot dry weight and $\mathrm{N}$ accumulation. Comparing plant growth and $\mathrm{N}$ uptake between plants grown in peat amended with wood vs. $100 \%$ peat may be a practical approach for growers and substrate manufacturers to evaluate peat:fiber and peat:wood substrates in horticultural practice.

Increasing the proportion of pine wood to greater than $30 \%$ of the substrate volume may require commercial growers to increase $\mathrm{N}$ fertilization and adjust irrigation practices to maintain optimal plant growth. Amended substrates in this study were primarily comprised of peat $(70 \%$ to $100 \%$ by volume). Previous research has consistently shown that increasing wood proportions tends to increase $\mathrm{N}$ immobilization (Handreck, 1993; Jackson et al., 2008; Prasad, 1996a; Wright et al., 2008 ), especially with greater than $40 \%$ wood by volume. In addition to $\mathrm{N}$ immobilization, certain wood materials can leach toxic compounds that inhibit plant growth into the rootzone (Bugbee and Heins, 2018; Bunt, 1988; Ortega et al., 1996), particularly if the wood has not been sufficiently aged or processed. Because wood components typically retain less water by volume compared with sphagnum peat (Argo, 1998a; Bugbee and Heins, 2018; Maher et al., 2008), greater proportions of wood may reduce substrate waterholding capacity and require more frequent irrigation. Based on results from this study, amending peat with $30 \%$ pine wood fiber or hammermilled pine wood would likely require minimal adjustment to the fertilizer and irrigation programs during production of container-grown petunia.

\section{Conclusions}

Reduced $\mathrm{N}$ accumulation in plant tissue was observed during the production phase when plants were grown with peat:fiber, and during the consumer phase with peat:wood, compared with $100 \%$ peat. However, results found peat substrate amended with 30\% pine wood fiber, hammermilled pine wood, and coconut coir had minimal effects on plant growth or the need to adjust the fertilization program during production of containerized petunia. All substrate treatments resulted in petunia with dark-green foliage and a marketable flower number at the end-ofproduction phase, and $\mathrm{N}$ concentrations remained within target ranges for petunia in both the shoot tissue and the root-zone. In the consumer phase, when plants were irrigated with deionized water (no fertilizer nutrients), substrate $\mathrm{N}$ became depleted in all substrates, and plants developed symptoms of leaf chlorosis and $\mathrm{N}$ deficiency. To reduce the risk of $\mathrm{N}$ depletion under clear-water irrigation, it would be desirable to provide residual fertilizer during the consumer phase regardless of the substrate.

\section{Literature cited}

Argo, W.R. and J.A. Biernbaum. 1993. Factors affecting garden performance of flowering plants in hanging baskets. Bedding Plants Foundation No. F-061A.

Argo, W.R. 1998a. Root medium physical properties. HortTechnology 8:481-485.

Argo, W.R. 1998b. Root medium chemical properties. HortTechnology 8:486494.

Argo, W.R. and P.R. Fisher. 2002. Understanding $\mathrm{pH}$ management for containergrown crops. Meister Publ., Willoughby, $\mathrm{OH}$.

Armitage, A.M. 1993. Bedding plants, prolonging shelf performance. Ball Publ., Batavia, IL.

Barrett, G.E., P.D. Alexander, J.S. Robinson, and N.C. Bragg. 2016. Achieving environmentally sustainable growing media for soilless plant cultivation systems: a review. Scientia Hort. 212:220-234.

Bilderback, T. 2009. A nursery friendly method for measuring air filled porosity of container substrates. Southern Nursery Assn. Res. Conf. 54:212-215.

Blok, C., C. de Kreij, R. Baas, and G. Wever. 2008. Analytical methods used in soilless cultivation, p. 245-289. In: M. Raviv and J.H. Lieth (eds.). Soilless culture, theory and practice. Elsevier, London, UK.

Bugbee, B. and R. Heins. 2018. Wood products in the root zone. 11 Nov. 2019. <https://gpnmag.com/article/woodproducts-in-the-root-zone $/>$.

Bunt, A.C. 1988. Media and mixes for container-grown plants. Unwin Hyman, London, UK.

Drotleff, L. 2018. HydraFiber soaks up horticulture market share with wood fiber media. 28 Dec. 2018. <https://www. greenhousegrower.com/production/ media/hydrafiber-soaks-up-horticulturemarket-share-with-wood-fiber-media/>.

de Oliviera, S.F., P.R. Fisher, J. Huang, and S.C. Mello. 2016. Strategies to provide fertilizer for both production and consumer phases of petunia. HortTechnology 26:164-175.

Fisher, P.R., R.W. Dickson, G.S. Mohammad-Pour, and J. Huang. 2014. Effect of solution electrical conductivity (EC) and pre-plant nutrient form on the $\mathrm{pH}$ of peat-perlite substrate. Acta Hort. 1034:249-254.

Geisseler, D., W.R. Horwath, R.G. Joergensen, and B. Ludwig. 2010. Pathways of nitrogen utilization by soil microorganisms: A review. Soil Biol. Biochem. 42:2058-2067.

Gibson, J.L., D.S. Pitchay, A.L. WilliamsRhodes, B.E. Whipker, P.V. Nelson, and J.M. Dole. 2007. Nutrient deficiencies in bedding plants, a pictorial guide for identification and correction. Ball Publ., Batavia, IL.

Gruda, N., S. von Tucher, and W.H. Schnitzler. 2000. N-immobilization by wood fiber substrates in the production of tomato transplants. J. Appl. Bot. Food Qual. 74:32-37.

Handreck, K.A. 1992a. Rapid assessment of the rate of nitrogen immobilisation in organic components of potting media: I. Method development. Commun. Soil Sci. Plant Anal. 23:201-215.

Handreck, K.A. 1992b. Rapid assessment of the rate of nitrogen immobilisation in organic components of potting media: II. Nitrogen drawdown and plant growth. Commun. Soil Sci. Plant Anal. 23:217230.

Handreck, K.A. 1993. Use of the nitrogen drawdown index to predict fertilizer nitrogen requirements in soilless potting 
media. Commun. Soil Sci. Plant Anal. 24:2137-2151.

Jackson, B.E., R.D. Wright, and M.C. Barnes. 2008. Pine tree substrate, nitrogen rate, particle size, and peat amendment affect poinsettia growth and substrate physical properties. HortScience 43:2155-2161.

Jackson, B.E., R.D. Wright, and M.M. Alley. 2009. Comparison of fertilizer nitrogen availability, nitrogen immobilization, substrate carbon dioxide efflux, and nutrient leaching in peat-lite, pine bark, and pine tree substrates. HortScience 44:781-790.

Maher, M., M. Prasad, and M. Raviv. 2008. Organic soilless media components, p. 459-504. In: M. Raviv and J.H. Lieth (eds.). Soilless culture, theory and practice. Elsevier, London, UK.

Mills, H.A. and J.B. Jones, Jr. 1996. Plant analysis handbook, Vol. 2: A practical sampling, preparation, analysis, and interpretation guide. MicroMacro Publ., Athens, GA.

Nelson, P.V. 2011. Greenhouse operation and management. 7th ed. Prentice Hall, Upper Saddle River, NJ.
Ortega, M.C., M.T. Moreno, J. Ordovás, and M.T. Aguado. 1996. Behavior of different horticultural species in phytotoxicity bioassays of bark substrates. Scientia Hort. 66:125-132.

Owen, G.W., B.E. Jackson, B.E. Whipker, and W.C. Fonteno. 2016. Pine wood chips as an alternative to perlite in greenhouse substrates: Nitrogen requirements. HortTechnology 26:199-205.

Prasad, M. 1980. Retention of nutrients by peats and wood wastes. Scientia Hort. 12:203-209.

Prasad, M. 1996a. Physical, chemical and biological properties of coir dust. Acta Hort. 450:21-29.

Prasad, M. 1996b. Nitrogen fixation of various material from a number of European countries by three nitrogen fixation tests. Acta Hort. 450:353-362.

Purcell, L.C. and C.A. King. 1996. Total nitrogen determination in plant material by persulfate digestion. Agron. J. 88:111-113.

Puustjarvi, V. and R.A. Robertson. 1975. Physical and chemical properties, p. $23-$ 38. In: D.W. Robinson and J.G.D. Lamb (eds.). Peat in horticulture. Academic Press, London, UK.

Raviv, M. 2005. Production of highquality composts for horticultural purposes: A mini-review. HortTechnology 15:52-57.

Schulten, H.R. and M. Schnitzer. 1998. The chemistry of soil organic nitrogen: A review. Biol. Fertil. Soils 26:1-15.

Association of German Agricultural Analytic and Research Institutes (VDLUFA). 2007. Methodenbuch I-Die Untersuchung von Böden: Methode A 13.5.1 Stabilität N-Haushalt. 7. Teillieferung. Assn. German Agr. Analytic Research Inst., Speyer, Germany.

Wright, R.D. 1986. The pour through nutrient extraction procedure. HortScience 21:227-229.

Wright, R.D., B.E. Jackson, J.F. Browder, and J.G. Latimer. 2008. Growth of chrysanthemum in a pine tree substrate requires additional fertilizer. HortTechnology 18:111-115. 